\title{
Pendidikan Literasi Berbasis Alquran dalam Tinjauan Teologis, Historis, dan Sosiologis
}

\author{
Thoriq Aziz Jayana \\ IAIN Madura \\ Email: azizjthoriq@yahoo.com
}

\begin{abstract}
The Qur'an has brought the spirit of literacy since the beginning of Islam, from that spirit then made Muslims recorded in world history as people who have created a superior civilization that became the mecca of science. This paper seeks to describe more complexly the spirit of literacy in the Qur'an from various aspects ranging from theological, historical, and sociological reviews. The research method used is literature with content analysis through interpretation of meaning. This article is a discourse study to dig deeper into the literacy spirit that needs to be applied in Islamic society. As a result, there are many verses in the Qur'an that command literacy by mentioning literacy tools and inviting mankind to think deeply, seek knowledge, and make bookkeeping a tradition. The scope of literacy is very broad, starting from reading, observing, researching, understanding, analyzing, criticizing, and so on.
\end{abstract}

Keywords: Literacy Education, Literacy Spirit, Alquran

\begin{abstract}
Abstrak
Alquran telah membawa spirit literasi sejak awal keislaman, dari spirit tersebut kemudian menjadikan umat muslim tercatat dalam sejarah dunia sebagai umat yang pernah menciptakan peradaban unggul yang menjadi kiblat ilmu pengetahuan. Tulisan ini berupaya untuk memaparkan lebih kompleks terhadap spirit literasi dalam Alquran dari berbagai aspek mulai dari tinjauan teologis, historis, dan sosiologis. Metode penelitian yang digunakan ialah kepustakaan dengan analisis konten melalui interpretasi makna. Artikel ini adalah kajian wacana untuk menggali lebih dalam tentang spirit literasi yang perlu diterapkan dalam masyarakat Islam. Hasilnya ditemukan banyak ayat dalam Alquran yang memerintahkan literasi dengan menyebut piranti-piranti literasi seraya mengajak umat manusia untuk berpikir secara mendalam, mencari ilmu pengetahuan, serta mentradisikan pembukuan. Cakupan literasi itu sangat luas mulai dari membaca, mencermati, meneliti, memahami, menganalisis, mengkritisi, dan sebagainya.
\end{abstract}

Kata Kunci: Pendidikan Literasi, Spirit Literasi, Alquran

\section{A. Pendahuluan}

Spirit pertama yang disampaikan oleh Tuhan dalam Al-Quran yakni iqra', yang berarti 'membaca', ialah wahyu permulaan yang diturunkan kepada Nabi Muhammad. ${ }^{1}$ Makna yang lebih luas dari kata tersebut, menurut Quraish Shihab, ialah menyampaikan, menelaah, membaca, mendalami, meneliti, mengetahui ciri-ciri, dan sebagainya, yang berujung pada

${ }^{1}$ Lihat diantaranya: Muhammad bin Ahmad bin Abi Bakar Al-Qurthubi, Al-Jami' li Abkam al-Quran, Vol. 22, (Beirut: Ar-Risalah, 2006), 374. Abu Fida Ismail bin Umar Ibn Katsir, Tafsir Al-Qur'an Al-'Adzim, Vol. 8, (Riyadh: Dar Thayyibah, 1997), 437, dan lainnya. 
Pendidikan Literasi Berbasis Alquran dalam Tinjauan ...

kata 'menghimpun'. ${ }^{2}$ Demikian pula masih banyak term-term dalam Al-Quran yang berindikasi dengan kegiatan literasi, seperti al-qalam, al-kitab, raqq, shubuf, dan sebagainya. Hakikatnya, berbagai term itu menjadi spirit berliterasi, mengakses, dan menyebarkan ilmu pengetahuan dalam Islam.

Namun, nampaknya spirit literasi tersebut belum menjadi kesadaran bagi umat Islam sendiri saat ini, hingga kini perkembangan keilmuan Islam cenderung detensif dan pasif. Prestasi yang pernah dicapai oleh ulama terdahulu, pada masa kejayaan Islam, dianggap sebagai sesuatu yang telah final dan tidak perlu dikonstruksi ulang. Persepsi yang demikian lah yang menyebabkan umat Islam jumud, serba taklid, dan minim karya intelektual. ${ }^{3}$ Artinya, umat Islam cenderung illiterate meski dalam kitab sucinya membawa spirit literasi. Konsekuensi yang lebih fatal dari sikap abai terhadap literasi ialah tidak mampu membangun pemikiran kritis dan kreatif dalam menjawab berbagai fenomena kehidupan, ${ }^{4}$ termasuk dalam kehidupan beragama.

Padahal kejayaan Islam, yang membuatnya masyhur di berbagai belahan dunia, mulai dari Timur hingga Barat dan Eropa, Islam dikenal sebagai agama yang cinta ilmu pengetahuan. Bermula dari tradisi baca-tulis, kemudian para ulama dan ilmuan muslim menghasilkan berjibun karya intelektual sehingga terbangun peradaban yang besar. Islam pernah menjadi kiblat ilmu pengetahuan dunia. Pada tahun 859 M berdiri Universitas AlQawariyyin, uniersitas pertama di dunia yang digagas oleh Fatimah Al-Fihri di Maroko. Pada tahun 975 M berdiri Universitas Al-Azhar di Mesir yang tetap kokoh sampai sekarang, dan kemajuan lainnya. ${ }^{5}$ Maka tidak berlebihan jika disebutkan bahwa literasi dalam Islam sebagai cikal-bakal lahirnya ilmu-ilmu keislaman dan ilmu pengetahuan. ${ }^{6}$

Di sisi lain, bisa dipahami bahwa literasi merupakan pendidikan dasar yang mesti diberikan dan wajib diupayakan kepada setiap umat Islam. Penekanan Islam terhadap pendidikan literasi sebagai asas dalam kewajiban mencari ilmu pengetahuan. Oleh karena itu, tulisan ini akan mengkaji tentang pendidikan literasi dalam perspektif Al-Quran yang ditinjau dari berbagai aspek: teologis, historis, dan sosiologi. Sehingga dari kajian tersebut

${ }^{2}$ M. Quraish Shihab, Tafsir Al-Misbah: Pesan, Kesan, dan Keserasian Al-Quran, Vol. 15, (Jakarta: Lentera Hati, 2002), 454.

${ }^{3}$ Mujamil Qomar, Epistemologi Pendidikan Islam: dari Metode Rasional hingga Metode Kritik, (Jakarta: Erlangga, 2005), 259.

${ }^{4}$ Setyawan Pujiono, "Berpikir Kritis dalam Literasi Membaca dan Menulis Untuk Memperkuat Jati Diri Bangsa", dalam Kusneni Hadidarsono, dkk, Prosiding Bahasa dan Sastra Indonesia ke-34. (2012), 778.

5 Zamakhsyari Abdul Majid, "Refleksi Al-Quran dalam Literasi Global: Studi Tafsir Maudhu'i dalam Kajian Literasi”, Al-Marhalab: Jurnal Pendidikan Islam, Vol. 3, No. 2, (2019), 83.

6 Ali Romdhoni, "Al-Quran Memerangi Illiteracy, Mencipta Peradaban Ilmu Pengetahuan", Journal of Qur'an and Hadith Studies, Vol. 1, No.1, (2012), 4. 
diharapkan mampu memberikan kontribusi integratif dalam membangun pemahaman dan kesadaran umat Islam terhadap literasi.

\section{B. Konsep Dasar Pendidikan Literasi}

Secara harfiah, kata literasi berakar dari literatus yang berarti 'ditandai dengan huruf' atau melek huruf atau dimaknai pula sebagai orang berpendidikan. ${ }^{7}$ Dalam bahasa Latin, orang yang bisa baca-tulis disebut literatus, sedangkan yang tidak bisa melakukannya disebut illiterat. ${ }^{8}$ Sehingga secara pemahaman dasar bahwa literasi adalah kemampuan bacatulis atau melek aksara.

Bila ditinjau secara maknawi, menurut Djoko Saryono, bahwa literasi ialah kebiasaan membaca dan menulis yang pada akhirnya menghasilkan kemampuan berpikir kritis dan kreatif, dari kemampuan berpikir tersebut maka seseorang bisa menyaring dan menilai informasi. ' Sementara itu, menurut Ali Romdhoni bahwa literasi kesadaran atas pentingnya mengakses informasi dan pengetahuan yang dari itu akan menghasilkan peradaban. ${ }^{10}$ Terkait pemahaman tersebut, Sarwiji Suwandi memberikan catatan bahwa perkembangan makna literasi akan terus bergerak dinamis sesuai dinamika kebudayaan, sehingga tidak menutup kemungkinan terhadap perluasan makna. ${ }^{11}$

Dalam konteks pendidikan, literasi adalah pelajaran utama yang wajib diberikan. Demikian pula, pendidikan tidak bisa dilepaskan dari kegiatan literasi. Keduanya bagai dua sisi mata uang yang tidak bisa dipisahkan. Kegiatan literasi seperti membaca, berpikir, dan menulis merupakan kegiatan yang perlu dilatih dan ditingkatkan, bahkan dalam pembelajaran yang paling dasar. Hal itu wajib diupayakan agar peserta didik mampu mengakses, mengolah, dan mentransfer informasi atau pengetahuannya. Mengingat akan hal tersebut, secara sederhana, pendidikan literasi bisa dimaknai sebagai kegiatan literasi yang wajib diberikan sebagai upaya pendidikan.

Di sisi lain, menurut Suwandi, aspek pendidikan literasi dapat dilihat sebagai pencapain kognitif individu yang secara tidak langsung dilihat sebagai aktivitas kolaboratif yang pada intinya bersifat interaktif yang tertanam dalam tujuan pendidikan. Sebagai usaha belajar, literasi tidak serta merta hadir secara alamiah, namun harus dimulai dari minat.

\footnotetext{
${ }^{7}$ Uus Toharudin, dkk, Membangun Literasi Sains Peserta Didik (Bandung: Humaniora, 2011), 1.

${ }^{8}$ Yosal Iriantara, Literasi Media: Apa, Mengapa, dan Bagaimana. Edisi Revisi. (Bandung: Simbiosa, 2017), 3.

${ }^{9}$ Djoko Saryono, Literasi Episentrum Kemajuan Budaya dan Peradaban (Malang: Pelangi Sastra, 2019), 4.

10 Ali Romdhoni, Al-Quran dan Literasi: Sejarah Rancang Bangun Ilmu-ilmu Keislaman (Depok: Literatur

11 Sarwiji Suwandi, Pendidikan Literasi: Membangun Budaya Belajar, Profesionalisme Pendidik, dan Budaya Kewirausahaan untuk. Mewujudkan Marwah Bangsa (Bandung: Remaja Rosdakarya, 2019), 9.
} Nusantara, 2013), 98. 
Pendidikan Literasi Berbasis Alquran dalam Tinjauan ...

Minat untuk mengakses informasi dan ilmu pengetahuan ialah melalui aktivitas membaca dan menulis. ${ }^{12}$

\section{Hasil dan Pembahasan}

Dalam konteks Islam, pendidikan literasi sudah ada semenjak awal keislaman. Bahkan bisa dikatakan bahwa keberadaan literasi sudah setua keberadaan Islam, sebagaimana wahyu pertama yang diturunkan kepada Nabi Muhammad yakni Surat Al-'Alaq: 1-5, yang di dalamnya mengandung perintah membaca, al-qalam, dan merenungkan penciptaan. Literasi Qur'ani itulah yang kemudian menyejarah dan menjadikan Islam sebagai agama peradaban. Untuk mengetahui sejauh mana kiprah pendidikan literasi dalam Islam (dalam konsep Al-Quran), maka dalam hal ini bisa ditinjau dari beberapa aspek yakni teologis, historis, dan sosiologis.

\section{Literasi Qur'ani dalam Tinjauan Teologis}

Sebagaimana disinggung di bagian awal, bahwa wahyu pertama yang diturunkan kepada Nabi Muhammad ialah Surat Al-'Alaq [96]: 1-5. Dalam ayat tersebut setidaknya mengandung tiga aspek utama yakni 1) perintah iqra' (membaca), 2) merenungkan penciptaan manusia, 3) konsep al-qalam (menulis) dan menyebarkan ilmu pengetahuan. Berbagai aspek tersebut yang kemudian menjadikan Al-Quran sebagai motivasi masyarakat Arab (Islam) untuk menciptakan budaya literasi.

Selain penggunaan term iqra' sebagai ungkapan 'membaca', dalam al-Quran juga menggunakan istilah tilawah dan tartil. Perintah membaca dengan term iqra' atau qara'a terdapat dalam surat Al-'Alaq [86]: 1-3, Al-Nahl [16]: 98, Al-Isra’ [17]: 14, term-term sejenis juga terdapat dalam Al-A'la [87]: 6, Al-Isra' [17]: 45, Yunus [10]: 94, dll. Sementara perintah membaca dengan term tala atau tilawah terdapat dalam Al-Baqarah [2]: 121, 252 Al-Maidah [5]: 27, Al-Naml [27]: 92, dll. Adapun perintah membaca dengan term rattil atau tartil terdapat dalam surat Al-Muzammil [73]: 4, Al-Furqan [25]: 32. Semua term tersebut berisi tentang ungkapan 'membaca'.

Ketiga ungkapan 'membaca' tersebut memiliki perbedaan spesifikasi penafsiran. Ungkapan iqra' atau qara'a merupakan kegiatan membaca yang melibatkan proses kognisi manusia yakni memahami, menelaah, melafalkan, mempelajari, menganalisa, dan seterusnya, tidak peduli ada objek atau tidak. Sedangkan tilawah menekankan pada aspek pengamalan atau tindakan praktis mengikuti isi bacaan. Adapun makna tartil menitik beratkan pada bacaan-bacaan yang teratur, khusyuk, tidak bosan, dan tidak berlebihan. ${ }^{13}$

\footnotetext{
12 Ibid, 21.

${ }^{13}$ Bandingkan: Sandi Wahid Rahmat Nugraha \& Irwan Abdurrohman, "Makna Qiraah dan Tilawah dalam Al-Quran Perspektif Teori Anti Sinonimitas Muhammad Syahrur”, Al-Bayan: Jurnal Studi Ilmu Al-Quran dan Tafsir,
} 
Dalam pemahaman tersebut jelas bahwa model membaca iqra' atau qira'ah melibatkan proses kognisi manusia sehingga ia bisa berpikir secara lebih mendalam.

Penafsiran terhadap kata iqra' sendiri (dalam Surat Al-'Alaq [86]: 1-3) terdapat dua kutub utama di dalam kajian tafsir. Sebagian ulama menafsirkannya sebagai amr taklifi, yakni seruan Allah yang menyangkut perbuatan sehingga wajib diupayakan dan dilatih. Pemahaman ini diikuti oleh Ibnu 'Asyur, M. Quraish Shihab, dll. ${ }^{14}$ Sementara sebagian ulama yang lain menafsirkan perintah iqra' tersebut sebagai amr takwini, yakni kemampuan membaca secara aktual dalam diri seseorang, sehingga lebih menggantungkan pada kekuasaan Allah. Pemahaman seperti ini diikuti oleh ulama-ulama seperti Muhammad Abduh, Al-Qurthubi, Hamka, dll. ${ }^{15}$ Kedua kutub penafsiran tersebut, sejatinya, saling melengkapi bila diaplikasikan dalam kondisi sekarang bahwa dalam melakukan pembacaan secara cermat (iqra) perlu diupayakan secara terus-menerus seraya disandarkan kepada kekuasaan Allah.

Konteks pemahaman iqra'sangat luas, begitu pula dalam relisasinya. Menurut Shihab, realisasi perintah iqra' tersebut tidak mengharuskan adanya suatu teks tertulis sebagai objek bacaan, dan tidak pula harus diucapkan sehingga terdengar orang lain. Maka pemaknaan iqra' ini sangat luas, meliputi menyampaikan, menelaah, membaca, mendalami, meneliti, mengetahui ciri-ciri sesuatu, dan sebagainya yang semuanya bermuara pada kata menghimpun. ${ }^{16}$ Begitu pula objek yang dibaca bukan hanya terbatas pada apa yang tertutlis (buku/kitab) namun termasuk realitas kehidupan, muhasabah diri, dan keberadaan alam semesta juga menjadi objek yang perlu dibaca.

Kegiatan pembacaan itu tentunya harus dilandasi dengan niat yang baik, niat karena Allah, sehingga dalam Surat Al-'Alaq disebutkan bahwa ketika melakuka iqra' harus dilandasi dengan bismi rabbika (dengan nama Tuhanmu). Masih menurut Shihab, kata tersebut merupakan mulabasah (penyertaan). Maksudnya, mengaitkan aktivitas membaca dengan nama Tuhan yang akan mengantarkan pelakunya untuk tidak melakukannya kecuali karena Allah, yang dalam hal ini akan menghasilkan keabadian dan keikhlasan. ${ }^{17}$ Hal tersebut juga menunjukkan bahwa dalam melakukan pembacaan harus diawali dengan

Vol. 5, No. 1, (2020), 52. Mirsa Nur Aini, Mutiara Fahrunnisa, \& Ridha Amalinda Lazuardi, "Analisis Sinonim dan Antonim Kata al-Qira'ah, Tilawah, dan Tartil dalam Al-Quran”, Semnasbama, Vol. 2, (2018), 753

${ }^{14}$ Ibnu 'Asyur, At-Tahrir wa At-Tanwir, Juz 30, (Tunisia: Dar At-Atunisiyah li An-Nasyr, 1984), 435. Dan, Shihab, Tafsir Al-Misbah, Volume 15, 454-460.

15 Muhammad Abduh, Tafsir Juz. 'Amma, Terjm. Mohd Syamsuri Yoesoef, dkk. (Bandung: Sinar Baru, 1993). Hamka, Tafsir Al-Azhar, Juz 30, (Jakarta: Pustaka Panji Mas, 1982), 215. Imam Al-Qurthubi, Al-Jami’ li Abkam Al-Quran, Jilid 22, (Beirut: Ar-Risalah, 2006), 376-377.

${ }^{16}$ Shihab, Tafsir Al-Misbah, Vol 15, 454.

17 Shihab, Tafsir Al-Misbah, Vol 15, 456. 
Pendidikan Literasi Berbasis Alquran dalam Tinjauan ...

kesadaran untuk memilih bahan-bahan bacaan yang sekiranya tidak mengantarkannya kepada hal-hal yang bertentangan dengan "nama Allah". ${ }^{18}$

Demikian pula dengan konsep al-qalam. Terdapat beberapa perbedaan tentang memaknai term al-qalam. Shihab, misalnya, mengartikan al-qalam sebagai hasil dari penggunaan alat, yakni tulisan. Bukan merujuk pada alat itu sendiri, tapi akibat darinya. Sedangkan Hamka, diantaranya, mengartikan sebagai alat mencatat (pena), pena sebagai pembuka cakrawala ilmu-ilmu Allah. Dari prinsip al-qalam ini bisa dipahami bahwa seseorang harus produktif dan berkreativitas atas hasil apa yang dibacanya. Kegiatannya berupa menulis, melukis, merekam, mendesain, dan sebagainya.

Selain term iqra' dan al-qalam, dalam Al-Quran terdapat term-term lain yang menyongsong semangat literasi. Menurut Romdhoni, kegiatan literasi yang dimaksud ialah berupa perintah membaca, menulis, manajemen pembukuan, serta perintah mencari (mengakses) dan memperdalam ilmu pengetahuan. Misalnya saja Al-Quran menyebutkan piranti baca-tulis, diantaranya; miqdad (tinta) dalam surat Al-Kahfi [19]: 109 dan Luqman [31]: 27, qalam (pena) terdapat dalam Al-Qalam [68]: 1, Al-'Alaq [96]: 3, dan Ali Imran [3]: 44.

Term qirthas (kertas) dalam Surat Al-An'am [6]: 7 dan 9, lauh (batu tulis) dalam AlQamar [54]: 13, Al-Buruj [85]: 21, Al-A'raf [7]: 145, Al-Muddatstsir [74]: 27-29, raqq (lembaran) dalam At-Thur [52]: 1-3, Al-Muzammil [73]: 8-9, Al-Kahfi [18]: 9, dan terma shubuf (helaian kertas) terdapat dalam Surat 'Abasa [80]: 12-13, Al-Zukhruf [43]: 71, AlNajm [53]: 36, Al-A'la [87]: 18, Al-Muddatstsir [74]: 52, Al-Takwir [81]: 10, Al-Bayyinah [98]: 2, Thaha [20]: 133, Al-A'la [87]: 18, serta lainnya. ${ }^{19}$

Perintah mencari ilmu pengetahuan diantaranya dalam Surat Al-Baqarah [2]: 31, AlA'raf [7]: 179, Al-Nisa' [4]: 49, Al-Jumu'ah [62]: 2, Al-Mujadalah [58]: 11, Al-Nahl [16]: 43, Al-Zumar [39]: 9, Al-Taubah [9]: 122, dan sebagainya. Perintah manajemensi pembukuan tertera dalam surat Al-Nur [24]: 33 dan Al-Baqarah [2]: 282, dan sejenisnya. Ayat tersebut mengarahkan pada fungsionalisasi tulisan sebagai bukti otentik yang efektif untuk perdagangan. Pada prinsipnya, keberadaan term-term yang demikian dalam Al-Quran menunjukkan pentingnya tradisi literasi baca-tulis ${ }^{20}$ yang perlu diterapkan sebagai salah satu perintah Tuhan kepada umat muslim.

\footnotetext{
${ }^{18}$ M. Quraish Shihab, Membumikean Al-Quran, 263.

${ }^{19}$ Romdhoni, Al-Quran dan Literasi, 82.

${ }^{20}$ Ibid, 80-81. Lihat pula M. Quraish Shihab, Membumikan Al-Quran: Fungsi dan Peran Wabyu dalam Kebidupan Masyarakat, (Bandung: Mizan, 1999), 44-45.
} 


\section{Literasi Qur'ani dalam Tinjauan Historis}

Motivasi literasi Al-Quran tidak bisa dilepaskan dari sejarah Bangsa Arab, dimana AlQuran diturunkan. Kondisi masyarakat Arab yang saat itu dikenal sebagai masyarakat ummi, lebih menekankan pada transmisi lisan ketimbang tulisan. Menurut sebagian ahli sejarah, bahwa mayoritas masyarakat Arab pra-Islam sudah mengenal tradisi baca-tulis, dengan ditemukannya berbagai prasasti dan abjad-abjad kuno di berbagai media. ${ }^{21}$ Sebagian sejarawan lain menyebut masyarakat Arab buta aksara, yang betul-betul belum mengenal tradisi baca-tulis, sehingga kedatangan Islam memotivasi masyarakat Arab untuk mentradisikan baca-tulis. ${ }^{22}$

Dari dua pandangan di atas nampaknya perlu dianalisis lebih mendalam apakah masyarakat Arab pra-Islam memang betul-betul niraksara atau tidak. Mengingat kondisi Arab saat itu sebagai jalur perdagangan dan seringnya diadakan kompetisi-kompetisi syair yang kemudian syair terbaik digantung di dinding Kakbah (múallaqat) serta ditulis dengan tinta emas (mudrahabat) $)^{23}$ hal itu tidak bisa menegasikan bahwa masyarakat Arab bisa bacatulis.

Namun di sisi lain mengingat tidak adanya catatan atau pendokumentasian hasil kebudayaan dan peradaban Arab saat itu, ditambah dengan kelangkaan dan minimnya alat tulis, serta kebiasaan masyarakat Arab yang mementingkan tradisi lisan dan hafalan, maka hal tersebut juga menjadi pertimbangan bahwa masyarakat Arab pra-Islam memang meninggalkan literasi baca-tulis. Oleh sebab itu bisa dikatakan bahwa sebenarnya masyarakat Arab pra-Islam sudah mengenal tulisan, dan sebagian diantara mereka bisa baca-tulis, namun dalam lingkup yang sederhana dan terbatas.

Literasi yang sederhana dan terbatas tersebut, bagi masyarakat Arab pra-Islam, hanya digunakan untuk hal-hal tertentu (seperti menulis syair dan kepentingan perniagaan) dan hanya sebagian kecil orang yang bisa baca-tulis. Literasi saat itu bukanlah sebagai kesadaran untuk membangun peradaban dan transmisi intelektualitas, tapi hanya untuk kepentingan-kepentingan yang spesifik. Mereka lebih mementingkan tradisi lisan dan hafalan, ketimbang tradisi tulisan. Sehingga kecerdasan seseorang kala itu diukur dengan

${ }^{21}$ Menurut pandangan ini bahwa masyarakat pra-Islam sudah mengenal tradisi baca-tulis selama berabadabad sebelum datangnya Islam. Beberapa prasasti yang ditemukan di Barat Laut Arab seperti abjad Nabatean, Lihyanik, Tsamudik, dan tulisan di tembok kuil kuno Syiria. Hal itu sebagai bukti bahwa masyarakat Arab praIslam sudah mengenal baca-tulis. Lihat: Taufik Adnan Amal, Rekonstruksi Sejarah Al-Quran, Jakarta: Pustaka Alvabet, 2005), 137.

${ }^{22}$ Hasan Ibrahim Hasan, Sejarah dan Kebudayaan Islam, Terjm. A. Bahauddin, (Jakarta: Kalam Mulia, 2006), 108. Lihat pula, Philip K. Hitti, History of the Arab, (London: Macmillan Education, 1970), 30-32.

${ }^{23}$ Haeruddin, "Karakteristik Sastra Arab pada Masa Pra-Islam”, Nady Al-Adab, Vol. 12, No. 2, (2016), 44. 
Pendidikan Literasi Berbasis Alquran dalam Tinjauan ...

kemampuan menghafalnya. Sedangkan orang yang bisa menulis dianggap suatu aib dan kelemahan berpikir, bahkan dinilai sebagai kerasukan makhluk gaib. ${ }^{24}$

Kedatangan Islam dengan membawa spirit iqra' dan qalam telah mengubah tradisi lisan menjadi tradisi literasi, dari tradisi literasi kemudian meghasilkan tradisi intelektual. Oleh sebab itu, Al-Maraghi menyatakan bahwa Al-Quran telah mengubah suatu bangsa yang rendah menjadi bangsa yang agung dengan perantara qalam. Jika tidak ada tulisan, maka ilmu tidak tercatat, dan agama akan sirna. ${ }^{25}$

Keberhasilan Islam dalam mentradisikan dan menyejarahkan literasi bagi masyarakat Arab hal itu menempati posisi penting dalam kaitannya dengan bangunan ilmu keislaman. Dalam catatan sejarah, untuk mentradisikan literasi (baca-tulis), Rasulullah selalu memotivasi para sahabatnya agar belajar menulis, kemudian melibatkan mereka dalam pencatatan wahyu (kuttab al-waby). Menurut Al-Zanjani setidaknya ada 34 orang sahabat yang bertugas mencatat wahyu, diantaranya Mu'awiyah, Ubay bin Ka'ab, Zayd bin Tsabit, Abdullah bin Mas'ud, Abu Musa Al-Asy'ari, dan lainnya. ${ }^{26}$ Bahkan untuk menggencarkan baca-tulis, Rasulullah meminta tawanan perang Badar, bila ingin mendapatkan kebebasan, maka harus mengajari baca-tulis kepada anak-anak kaum muslimin di Madinah. ${ }^{27}$

Selanjutnya, kegiatan literasi bukan hanya terbatas pada kegiatan baca-tulis, namun lebih kompleks lagi yakni menyangkut transmisi keilmuan Islam. Pada periode Makkah, Rasulullah lebih menekankan pada pengajaran teologi keislaman, pendidikan 'aqliyah dan ilmiyah, pendidikan akhlak, pendidikan jasmani dan kesehatan. ${ }^{28}$ Adapun pada periode Madinah merupakan penyempurnaan pendidikan sebelumnya, dimana Nabi melakukan pembinaan di bidang muamalah, sosial-politik, dan aspek-aspek kemanusiaan dalam mengelola serta menjaga kesejahteraan. ${ }^{29}$ Sehingga bisa dikatakan bahwa periode Madinah merupakan awal pergerakan Islam dalam membangun peradaban baru.

Literasi semakin membumi di kalangan umat Islam sebagai suatu tradisi keilmuan. Kegiatan literasi semakin pesat seiring dengan tersebarnya Islam ke berbagai wilayah sehingga bersentuhan dengan berbagai pemikiran dan ilmu pengetahuan. Pada tahun 25 H, Al-Quran disusun menjadi mushaf pada masa Khalifah Utsman bin Affan yang 75.

${ }^{24}$ M. M. Azami, Hadis Nabi dan Kodifikasinya, Terjm. Ali Musthofa Ya'qub, (Jakarta: Pustaka Firdaus, 1994),

25 Ahmad Musthafa Al-Maraghi, Tafsir Al-Maraghi, Vol. 1, (Kairo: Al-Bab Al-Himmi, 1992), 199.

26 Amal, Rekonstruksi Sejarah Al-Quran, 145.

27 Manna Khalil al-Qaththan, Pengantar Studi Ilmu Hadis, Terjm. Mifdhol Abdurrahman, Jakarta: AlKautsar, 2005), 46.

28 Zuhairini, Sejarah Pendidikan Islam, (Jakarta: Bumi Aksara, 2008), 27.

2.

${ }^{29}$ Abuddin Nata, Sejarah Pendidikan Islam pada Periode Klasik dan Pertengahan, (Jakarta: Raja Grafindo, 2004), 
kemudian dikirimkan ke berbagai wilayah kekuasaan Islam untuk diajarkan kepada umat muslim. Demikian pula dengan hadis, pada awal abad ke-2 H (abad ke-8 M) hadis berhasil dibukukan secara resmi, dan terus berkembang semakin pesat hingga abad ke-5 H (abad ke-11 M). ${ }^{30}$

Transmisi dan perkembangan keilmuan Islam semakin berjalan pesat dan mencapai puncaknya pada masa Bani Abbasiyah (750-1258 M), terutama pada masa kepemimpinan Harun Al-Rasyid (786-809 M) dan Al-Makmun (813-833 M). Pada masa itu muncul para tokoh ulama besar, teolog, filsuf muslim, ilmuan, dan sastrawan. Banyak diantara mereka yang membidangi berbagai keilmuan sekaligus, juga dibuktikan dengan produktifitas karya yang berjibun (prolifik). Disiplin keilmuan sangat beragam mulai dari tafsir Al-Quran, hadis, fikih, filsafat, kedokteran, sains, sastra, matematika, astronomi, geografi, arsitektur, dan penerjemahan karya-karya Yunani, Persia, dan India ke dalam Bahasa Arab. Dan tentunya difasilitasi penuh oleh negara dengan dibangunnya pusat keilmuan dan perpustakaan lengkap yang dikenal dengan bayt al-bikmah. ${ }^{31}$ Sehingga Islam menjadi pusat keilmuan dan peradaban dunia saat itu.

Namun tidak bisa dinegasikan bahwa umat Islam juga pernah mengalami masa kemunduran (dark age) yang terjadi sejak abad ke-13 hingga abad ke-17 M. Selain karena faktor kekacauan politik dan konflik internal maupun eksternal, ${ }^{32}$ juga disebabkan karena umat Islam semakin mengabaikan literasi. Lemahnya budaya literasi menjadikan umat Islam mudah bersikap taqlid, fanatik buta, eksklusif, mudah dibodohi, dan tidak bisa membedakan mana kebenaran dan mana kebohongan. Sikap kritis, analitis, inklusif, keratif, dan progresif yang dihasilkan dari pembiasaan literasi menjadi hilang dari diri umat Islam.

Oleh sebab itu dengan spirit literasi iqra' dan qalam telah memberikan bukti nyata terhadap peradaban Islam. Kejayaan Islam tidak bisa dilepaskan dari semangat literasi yang dibawa oleh Al-Quran, yang menjadikan Islam dicatat dengan 'tinta emas' dalam peradaban dunia. Dengan kata lain, bahwa peradaban Islam bertumpu atas budaya literasi. Dalam hal ini bisa dipahami bahwa bila umat Islam ingin kembali merebut kembali

${ }^{30}$ Ahmad Paishal Amin, "Historiografi Pembukuan Hadis Menurut Sunni dan Syi'ah", Al-Drikra: Jurnal Studi Ilmu Al-Qur'an dan Al-Hadits, Vol. 12, No. 1, (2018), 87.

${ }^{31}$ Suwarno, "Kejayaan Peradaban Islam dalam Perspektif Ilmu Pengetahuan", Islamadina: Jurnal Pemikiran Islam, Vol. 20, No.2, (2019), 168-170.

32 Faktor internal misalnya ambisi dan perbedaan mazhab keagamaan, bercampurnya syariat Islam dengan syariat di luar Islam, kemiskinan, ketertindasan, sistem kekhalifahan yang kacau. Sedangkan faktor eksternal seperti imperialisme, kolonialisme, dan peperangan. Lihat: Anang Sholikhudin, "Merebut Kembali Kejayaan Islam: Analisis Internal dan Eksternal Penyebab Kemunduran Islam", Al-Murabbi: Jurnal Pendidikan Agama Islam, Vol. 3, No. 1, (2017), 136-142. 
Pendidikan Literasi Berbasis Alquran dalam Tinjauan ...

kejayaan, maka literasi harus dibudayakan, sebab ia merupakan suatu keniscayaan dalam membangun peradaban dan mengembangkan ilmu pengetahuan. Hal tersebut sejatinya menjadi motivasi bagi umat Islam untuk terus membudayakan literasi dalam berbagai aspek kehidupan.

\section{Literasi Qur'ani dalam Tinjauan Sosiologis}

Berdasarkan laporan riset yang dilakukan oleh lembaga PIRLS (Progress in International Reading Literacy Study) pada tahun 2006, yang mengamati minat baca siswa sekolah dasar, dari 40 negara yang dijadikan sampel penelitian, posisi Indonesia berada pada urutan ke36. Siswa Indonesia hanya lebih baik dari Qatar, Kuwait, Maroko dan Afrika Selatan. ${ }^{33}$ Pada riset tahun 2011, oleh lembaga riset yang sama, menunjukkan bahwa kualitas literasi siswa Indonesia membaik dari sebelumnya, hanya saja bila dibandingkan dengan siswa di dunia internasional masih berada di level lemah, di bawah median internasional. ${ }^{34}$

Hal tersebut menjadi linier dengan laporan Komisi Penyiaran Indonesia (KPI), bahwa kegiatan anak menonton TV sekitar 4 hingga 5 jam sehari, bila dikalkulasikan dalam setahun memberikan kesimpulan bahwa jam menonton siaran TV bagi anak mencapai dua kali lipat dari jam sekolah. ${ }^{35}$ Artinya, budaya baca atau literasi di kalangan anak-anak Indonesia masih kalah populer dengan aktivitas menonton televisi atau aktivitas lainnya seperti bermain game. Maka tidak mengherankan bila mereka lebih mengenal nama-nama tayangan dan karekater-karakter gaming ketimbang materi pelajaran.

Hal ini menjadi problematika tersendiri yang mesti dicarikan solusi, mengapa masyarakat Indonesia dan negara-negara yang berpenduduk masyoritas muslim seperti Qatar, Kuwait, Maroko, dan Afrika Selatan berdasarkan riset PIRLS di atas masih berada jauh di bawah negara-negara 'sekuler' dalam bidang literasi. Sekali pun dalam Islam sudah termaktub jelas tentang motivasi literasi Qur'ani, namun dalam realitas umat muslim masih tidak begitu diperhatikan, atau malah diabaikan. Cara berpikir umat Islam-yang kebanyakan hidup di negara-negara berkembang_-nampaknya lebih cenderung pragmatis untuk hal-hal yang bersifat materialis, begitu pula dengan literasi karena dinilai tidak menguntungkan secara materi maka diabaikan. Sebaliknya, bagi masyarakat negara maju, literasi merupakan basis peradaban mereka.

Dampak yang lebih fundamental dari pengabaian terhadap literasi menyebabkan ketidakmampuan dalam membangun paradigma berpikir kritis, kreatif, dan produktif

${ }^{33}$ Muhsin Kalida dan Moh Mursyid, Gerakan Literasi Mencerdaskan Negeri, (Yogyakarta: Aswaja Pressindo, 2020), 104.

34 Maman Suryaman, "Analisis Hasil Belajar Peserta Didik dalam Literasi Membaca Melalui Studi Internasional (PIRLS) 2011”, Litera, Vol. 14, No. 1, (2015), 170.

${ }^{35}$ Kalida, Gerakan Literasi, 115. 
dalam menghadapi berbagai persoalan hidup. Salah satu contoh dari perilaku masyarakat yang mengabaikan literasi ialah tidak mempedulikan terhadap aturan-aturan yang jelas. Mereka akan tetap merokok sekali pun sudah tertulis "dilarang merokok". Dengan demikian, menurut Romdhoni, maka masyarakat yang niraksara tidak akan pernah tercerahkan untuk bisa mengatur diri sendiri. ${ }^{36}$

Sikap abai dan tidak mempedulikan literasi membuat masyarakat lebih mudah termakan berita hoax, ujaran kebencian (hate speech), terpapar paham radikalisme, dan prasangka isu-isu SARA yang sejatinya dapat memicu konflik horizontal. ${ }^{37}$ Terutama di era post-truth yang melahirkan banalitas kebohongan, sehingga seseorang sulit membedakan kebenaran dan kepalsuan secara jelas. Demikian pula dalam era disruption yang melahirkan pemahaman serba instan, sehingga seseorang merasa cukup membangun pengetahuannya lewat tontonan video dan artikel di media sosial. Dalam konteks inilah literasi sangat dibutuhkan, utamanya literasi media-informasi dan literasi moderasi beragama sangat. ${ }^{38}$

Budaya literasi yang dimiliki oleh masyarakat akan mempengaruhi sudut pandang yang terlibat dalam menghadapi problematika. Sebab literasi berbanding lurus dengan cakupan pengetahuan yang diperolehnya. Artinya, semakin kuat literasi masyarakat, maka akan semakin banyak informasi yang diterima, dan semakin luas cara pandang masyarakat tersebut, sehingga lahirlah kebijaksanaan dalam menyikapi persoalan. Hal ini sangat bermanfaat, mengingat arus informasi yang begitu cepat dan deras, sehingga ketidaktepatan dalam menerima informasi akan berdampak negatif pada kehidupan sosial masyarakat. ${ }^{39}$

Dengan demikian, maka perlu kehadiran seluruh kalangan, mulai dari pemerintah, tokoh agama, tokoh masyarakat serta komunitas-komunitas literasi untuk berkolaborasi dengan baik dalam menciptakan budaya pendidikan literasi bagi masyarakat. Hal ini perlu diawali dengan program-program literasi, penyediaan sarana literasi yang memadai, hingga dakwah-dakwah yang memacu literasi, semua itu untuk menumbuhkan kesadaran masyarakat akan hakikat dan pentingnya literasi dalam kehidupan.

\footnotetext{
${ }^{36}$ Romdhoni, Al-Quran dan Literasi, 95.

${ }^{37}$ Sabiruddin B. Juli, "Saring Sebelum Sharing: Menangkal Hoax, Radikalisme di Media Sosial", Al-Munir: Jurnal Komunikasi dan Penyiaran Islam, Vol. 10, No. 1, (2019), 22.

${ }^{38}$ Krisna Sukma Yogiswari \& Ida Bagus Putu Eka Suadnyana, "Hoax di Era Post-Truth dan Pentingnya Media Literasi", dalam I Gede Suwantara (Ed), Prosiding Seminar Nasional Filsafat I: Hoax dalam Perspektif Filsafat, (Denpasar: IHDN Press, 2019), 173. Aisyahnur Nasution, "Moderasi Beragama di Era Disrupsi Digital”, dalam Abdullah Munir, dkk, Literasi Moderasi Beragama di Indonesia, (Bengkulu: Zigie Utama, 2020), 20.

39 Dedi Wahyudi \& Novita Kurniasih, "Literasi Moderasi Beragama Sebagai Reaktualisasi Jihad Milenial Era 4.0”, Moderatio: Jurnal Moderasi Beragama, Vol. 1, No. 1, (2021), 32.
} 
Pendidikan Literasi Berbasis Alquran dalam Tinjauan ...

\section{Simpulan}

Ajaran Islam membawa spirit literasi dengan perintah iqra' dan al-qalam yang tertuang dalam wahyu pertama, Surat Al-'Alaq [96]: 1-5. Demikian pula dalam banyak ayat, Al-Quran memerintahkan literasi dengan menyebut piranti-piranti literasi dan mengajak umat manusia untuk berpikir secara mendalam, mencari ilmu pengetahuan, serta mentradisikan pembukuan. Cakupan literasi itu sangat luas mulai dari membaca, mencermati, meneliti, memahami, menganalisis, mengkritisi, dan sebagainya. Kemudian hasil dari pembacaannya itu dituangkan dalam karya sehingga dapat dibaca dan dipelajari oleh generasi selanjutnya. Pendidikan literasi dalam Islam telah memberikan bukti sejarah bahwa Islam pernah membangun peradaban yang unggul dan menjadi kiblat ilmu pengetahuan dunia. Belajar dari sejarah, bahwa bila suatu bangsa ingin menciptakan peradaban maju maka mulailah dengan menanamkan budaya literasi bagi masyarakatnya. Masyarakat yang literer memiliki wawasan yang luas, paradigma yang jelas, dan memiliki pandangan yang terbuka.

$* * * * * * * * *$

\section{Daftar Pustaka}

Abduh, M. 1993. Tafsir Juz 'Amma. Terjm. Mohd Syamsuri Yoesoef, dkk. Bandung: Sinar Baru.

Aini, M. N.; Fahrunnisa, M.; \& Lazuardi, R. A. 2018. "Analisis Sinonim dan Antonim Kata alQira'ah, Tilawah, dan Tartil dalam Al-Quran”. Semnasbama. Vol. 2. Link: http://prosiding.arab-um.com/index.

Al-Maraghi, A. M. 1992. Tafsir Al-Maraghi. Vol. 1. Kairo: Al-Bab Al-Himmi.

Al-Qurthubi, I. 2006. Al-Jami' li Abkam Al-Quran. Jilid 22. Beirut: Ar-Risalah.

Amal, T. A. 2005. Rekonstruksi Sejarah Al-Quran. Jakarta: Pustaka Alvabet.

Amin, A. P. 2018. "Historiografi Pembukuan Hadis Menurut Sunni dan Syi'ah". Al-Drilkra: Jurnal Studi Ilmu Al-Qur'an dan Al-Hadits. Vol. 12. No. 1. DOI: https://doi.org/10.24042/al-dzikra.v12i1.2926

Asyur, I. 1984. At-Tahrir wa At-Tanwir. Juz 30. Tunisia: Dar At-Atunisiyah li An-Nasyr.

Azami, M. M. 1994. Hadis Nabi dan Kodifikasinya. Terjm. Ali Musthofa Ya'qub. Jakarta: Pustaka Firdaus.

Haeruddin. 2016. "Karakteristik Sastra Arab pada Masa Pra-Islam". Nady Al-Adab. Vol. 12. No. 2. DOI: https://doi.org/10.20956/jna.v13i1.3231

Hamka. 1982. Tafsir Al-Az̧har. Juz 30. Jakarta: Pustaka Panji Mas.

Hasan, H. I. 2006. Sejarah dan Kebudayaan Islam. Terjm. A. Bahauddin. Jakarta: Kalam Mulia.

Hitti, P. K. 1970. History of the Arab. London: Macmillan Education. 
Juli, S. B. 2019. "Saring Sebelum Sharing: Menangkal Hoax, Radikalisme di Media Sosial". AlMunir: Jurnal Komunikasi dan Penyiaran Islam. Vol. 10. No. 1. DOI: https://doi.org/10.15548/amj-kpi.v2i1.486

Kalida, M.; \& Mursyid, M. 2020. Gerakan Literasi Mencerdaskan Negeri. Yogyakarta: Aswaja Pressindo.

Katsir, I.. 1997. Tafsir Al-Qur'an Al-Adrim. Vol. 8. Riyadh: Dar Thayyibah.

Majid, Z. A. 2019. "Refleksi Al-Quran dalam Literasi Global: Studi Tafsir Maudhu'i dalam Kajian Literasi". Al-Marbalah: Jurnal Pendidikan Islam. Vol. 3. No. 2. DOI: https://doi.org/10.38153/alm.v3i2.33

Nugraha, S. W. R.; \& Abdurrohman, I. 2020. "Makna Qiraah dan Tilawah dalam Al-Quran Perspektif Teori Anti Sinonimitas Muhammad Syahrur". Al-Bayan: Jurnal Studi Ilmu AlQuran dan Tafsir. Vol. 5. No. 1. DOI: https://doi.org/10.15575/al-bayan.v5i1.8939

Qomar, M. 2005. Epistemologi Pendidikan Islam: dari Metode Rasional hingga Metode Kritik. Jakarta: Erlangga.

Romdhoni, A. 2012. "Al-Quran: Memerangi Illiteracy, Mencipta Peradaban Ilmu Pengetahuan". Journal of Qur'an and Hadith Studies. Vol. 1. No.1. DOI: https://doi.org/10.15408/quhas.v1i1.1318

Romdhoni, A. 2013. Al-Quran dan Literasi: Sejarah Rancang Bangun Ilmu-ilmu Keislaman. Depok: Literatur Nusantara.

Saryono, D. 2019. Literasi Episentrum Kemajuan Budaya dan Peradaban. Malang: Pelangi Sastra.

Shihab, M. Q. 1999. Membumikan Al-Quran: Fungsi dan Peran Wabyu dalam Kebidupan Masyarakat. Bandung: Mizan.

Shihab, M. Q. 2002. Tafsir Al-Misbah: Pesan, Kesan, dan Keserasian Al-Quran. Vol. 15. Jakarta: Lentera Hati.

Sholikhudin, A. 2017. "Merebut Kembali Kejayaan Islam: Analisis Internal dan Eksternal Penyebab Kemunduran Islam”. Al-Murabbi: Jurnal Pendidikan Agama Islam. Vol. 3. No. 1. Link: https://jurnal.yudharta.ac.id/v2/index.php/pai/article/view/898

Suryaman, M. 2015. “Analisis Hasil Belajar Peserta Didik dalam Literasi Membaca Melalui Studi Internasional (PIRLS) 2011”. Litera, Vol. 14. No. 1. DOI: https://doi.org/10.21831/ltr.v14i1.4416

Suwandi, S. 2019. Pendidikan Literasi: Membangun Budaya Belajar, Profesionalisme Pendidik, dan Budaya Kewirausahaan untuk. Mewujudkan Marwah Bangsa. Bandung: Remaja Rosdakarya.

Suwarno. 2019. "Kejayaan Peradaban Islam dalam Perspektif Ilmu Pengetahuan”. Islamadina: Jurnal Pemikiran Islam. Vol. 20. No.2. DOI: http://dx.doi.org/10.30595/islamadina.v0i0.5105

Toharudin, U. 2011. Membangun Literasi Sains Peserta Didik. Bandung: Humaniora.

Wahyudi, D.; \& Kurniasih, N. 2021. "Literasi Moderasi Beragama Sebagai Reaktualisasi Jihad Milenial Era 4.0". Moderatio: Jurnal Moderasi Beragama, Vol. 1. No. 1. Link: https://ejournal.metrouniv.ac.id/index.php/ 
Pendidikan Literasi Berbasis Alquran dalam Tinjauan ... 